\title{
Particle size distribution in a heat-processed beverage prepared from roasted peanuts
}

\author{
M. J. Hinds, M. S. Chinnan* \& L. R. Beuchat \\ Center for Food Safety and Quality Enhancement, Department of Food Science and Technology, University of Georgia, Griffin, \\ GA 30223-1797, USA
}

\begin{abstract}
Fractional filtration was used to measure particle size in peanut beverages which were either bottle-processed $\left(2 \mathrm{~min}\right.$ at $72^{\circ} \mathrm{C}$ or $8 \mathrm{~min}$ at $\left.111^{\circ} \mathrm{C}\right)$ after homogenization $\left(20.7 \times 10^{6} \mathrm{~Pa}\right.$ at $\left.72^{\circ} \mathrm{C}\right)$ or kettle-pasteurized $\left(2 \mathrm{~min}\right.$ at 72,77 or $82^{\circ} \mathrm{C}$ ) before homogenization $\left(20.7 \times 10^{6} \mathrm{~Pa}\right.$ at 72,77 or $\left.82^{\circ} \mathrm{C}\right)$. To prepare beverages, partially-defatted roasted peanuts were milled and wet-blended, slurries were filtered through screens with $34 \mu \mathrm{m}$ mesh size, and filtrates were blended with sucrose, salt (sodium chloride) and stabilizer. After 14 days' storage, beverages contained 99.8 to $99.9 \mathrm{~g} / 100 \mathrm{~g}$ total solids with diameters $<34 \mu \mathrm{m}$. Harsher bottle-processing conditions or higher homogenizing temperatures, respectively, increased or decreased particle size. Homogenizing after heat treatment reduced the size of particles. Weights of particles retained on screens with 104-, 74 and $53-\mu \mathrm{m}$ openings from peanut beverages which were kettle pasteurized at 77 or $82^{\circ} \mathrm{C}$, then homogenized $\left(20.7 \times 10^{6} \mathrm{~Pa}\right)$ at 77 or $82^{\circ} \mathrm{C}$ were similar $(p \leq 0.05)$ to those retained from commercial low-fat and full-fat cows' milk but less than those retained from commercial chocolate low-fat milk or chocolate drink. Results indicate that the experimental beverages would be less chalky than commercial chocolate low-fat milk and chocolate drink. (O) 1997 Published by Elsevier Science Ltd on behalf of the Canadian Institute of Food Science and Technology
\end{abstract}

Keywords: peanut beverage, particle size, chalkiness, fractional filtration, roasted peanuts.

\section{INTRODUCTION}

There is an increasing demand for oilseed beverages as alternative sources of dietary protein, especially in countries where dairy products are expensive or in limited supply. Extensive studies have been carried out to improve the sensory attributes of beverages prepared from aqueous extracts of unroasted peanuts and soybeans (Schmidt et al., 1978; Chompreeda et al., 1989; Galvez et al., 1990; Lee \& Beuchat, 1992). A major undesirable characteristic of oilseed beverages is chalkiness (Kuntz et al., 1978; Rubico et al., 1987), the sensation of coating on a consumer's mouth and throat.

The sensory attribute 'smoothness' has been described as the feel on soft tissues (Szczesniak, 1979), and is inversely proportional to the force required to overcome

\footnotetext{
* To whom correspondence should be addressed.
}

the frictional resistance offered by food components as they move over the skin of the oral cavity (Kokini, 1987). When beverages are being consumed, frictional resistance is influenced by size, mass, density and distribution of the particles, and by the nature of the medium in which the particles are dispersed. As frictional resistance increases, smoothness decreases, and terms such as chalky and grainy are used to describe the sensation of mouthfeel.

Particulate characteristics of animal milk products arise mainly from casein micelles, fat globules, whey proteins and lactose molecules. In addition to protein and fat, imitation milks prepared from oilseeds contain cellulose particles from cell wall fragments which promote chalkiness (Kuntz et al., 1978). Procedures utilized to improve smoothness in milk products and oilseed beverages include various heat-processing protocols, homogenizing parameters, filtration and microparticu- 
lation. Size and distribution of particles in beverages are measured by various techniques including wet-sieving (Rubico et al., 1987), electrical impedance (Schmidt et al., 1978), photographic images such as scanning and transmission electron microscopy (Holcomb et al., 1992), photon correlation spectroscopy (Paquin et al., 1991) and evaluation of laser diffraction patterns (Banon \& Hardy, 1992).

Chalkiness in oilseed beverages is related to size distribution of particles, which may be influenced by the nature of the complexes formed during heat-processing. In a previous study, in which we evaluated the effects of heat processing methods on selected physical properties of a peanut beverage (Hinds et al., 1997a), defatted peanuts were wet-milled and slurries were filtered through a $34-\mu \mathrm{m}$ mesh screen. However, knowledge of particle size in heat-processed products would be necessary in order to select processing parameters which would give rise to a smooth beverage. The objectives of this study were to evaluate the effects of two heat processing methods on particle size distribution in a beverage prepared from partially-defatted roasted peanuts.

\section{MATERIALS AND METHODS}

\section{Materials}

Roasted $\left(163^{\circ} \mathrm{C}\right.$ for $\left.20 \mathrm{~min}\right)$, dry-blanched and electronically sorted Florunner cultivar peanut (Arachis hypogaea) seeds $\left(49 \mathrm{~g}\right.$ fat $100 \mathrm{~g}^{-1}$ seed, dry basis) were donated by Specialty Brands, Dromedary Plant, Woodbury, GA, USA. A blend of kappa:iota carrageenan $\left(3: 1\right.$, w:w, Benlacta CM-61B ${ }^{\circledR}$, Shemberg USA, Searsport, ME) and hydrogenated mono-diglyceride (Emuldan HV52K ${ }^{\circledR}$, Grinsted Products, Inc., Industrial Airport, KS) were donated by the respective companies. Granulated refined cane sugar, non- iodized salt and commercial beverages [Kroger ${ }^{\text {(i) Vitamin D (whole) }}$ milk, Kroger(i) low-fat milk, Yoo-hoo ${ }^{(i)}$ chocolate flavored drink, Kroger ${ }^{(m)}$ chocolate low-fat milk] were purchased from a local supermarket. Polyester screen materials (mesh nos. 126, 143, 280, 275 and 380) with openings of $125,104,74,53$ and $34 \mu \mathrm{m}$, respectively, were purchased from McMaster Company (Atlanta, GA). Sections of PVC pipes ( 81 and $87 \mathrm{~mm}$ i.d.) and cement (Oatey regular clear cement for PVC, Oatey, Cleveland, $\mathrm{OH}$ ) were purchased from a local hardware store.

\section{Beverage preparation}

Roasted $\left(163^{\circ} \mathrm{C}\right.$ for $\left.20 \mathrm{~min}\right)$ and blanched peanuts were obtained from Specialty Brands, Dromedary Plant, Woodbury, GA, USA. The peanuts were partially defatted $\left(24.5 \%\right.$ fat, dry basis) at $27.6 \times 10^{6} \mathrm{~Pa}$ for $5 \mathrm{~min}$ using a Carver Press (Model M, Fred S. Carver, Inc.,
Menomonee Falls, WI), finely ground in a Morehouse mill (Morehouse Industries, Los Angeles, CA), wet blehded (1:8, w:v), and filtered through a $34 \mu \mathrm{m}$ polyester mesh. The filtrate was mixed with sucrose $(3 \%)$ and salt $(0.05 \%)$ and heated in a steam-jacketed kettle. Stabilizers CM [carrageenan $\left(0.02 \%\right.$ Benlacta $\left.\mathrm{CM}-61 \mathrm{~B}^{(\mathrm{i})}\right)$ ] or HV [hydrogenated monodi-glyceride $(0.2 \%$ Emuldan HV52L $\left.\left.{ }^{(i)}\right)\right]$ were added to the slurry at $63^{\circ} \mathrm{C}$ which was then heated to $72^{\circ} \mathrm{C}$. The heated slurry was subjected to homogenizing and thermal processing to obtain a bottle-pasteurized or kettle-pasteurized beverage. For bottle-pasteurized beverages, each batch was homogenized at $72^{\circ} \mathrm{C}$ and $20.7 \times 10^{6} \mathrm{~Pa}$ before being bottled. Samples were then heat-processed at $72^{\circ} \mathrm{C}$ for $2 \mathrm{~min}$ or $111^{\circ} \mathrm{C}$ for $8 \mathrm{~min}$. Kettle-pasteurized beverages were heated at 72 , 77 or $82^{\circ} \mathrm{C}$ for $2 \mathrm{~min}$, homogenized $\left(20.7 \times 10^{6} \mathrm{~Pa}\right)$ at the same temperature at which they were pasteurized, bottled and capped. Beverages containing either $\mathrm{CM}$ or $\mathrm{HV}$ and heated in the kettle only to achieve a temperature of $72^{\circ} \mathrm{C}$ (without additional heat treatment and homogenization) served as controls.

\section{Physical analysis}

Solids contents $\left(\mathrm{g} 100 \mathrm{~mL}^{-1}\right)$ in peanut beverages and commercial beverages were determined according to procedures explained by Hinds et al. (1996b) after samples were held at $1^{\circ} \mathrm{C}$ for $7 \mathrm{~d}$. After 14 days at $1{ }^{\circ} \mathrm{C}$, particle size distribution in the beverages was determined by fractional filtration as described below. Triplicate determinations per treatment were carried out for each test.

\section{Particle size measurement}

Polyester screen materials (mesh nos. 126, 143, 208, 275, and 380) with mesh openings of $125,104,74,53$, and $34 \mu \mathrm{m}$, respectively, were used to fabricate sieves. A circular layer of polyester screen material was cemented to the base of a $41-\mathrm{mm}$ length of PVC pipe ( $81 \mathrm{~mm}$ i.d.). The screen material was then secured with a 44-mm length of PVC pipe $(87 \mathrm{~mm}$ i.d.) which also served as a permanent collar (Fig. 1). The sieve was then heated for $24 \mathrm{~h}$ in a Tenney Benchmaster dryer (Model Tenn Trol ${ }^{\circ}$ II, Tenney Engineering Inc., Union, NJ) set at $50^{\circ} \mathrm{C}$ to ensure complete drying of the adhesive. A small pump to apply air pressure was constructed using PVC pipe $(50 \mathrm{~mm}, 87 \mathrm{~mm}$ i.d.) to form the frame. The piston consisted of PVC (118 mm, $81 \mathrm{~mm}$ i.d.), at one end of which was affixed a PVC collar $(28 \mathrm{~mm}, 87 \mathrm{~mm}$ i.d.) onto which a circular sheet of polystyrene $(87 \mathrm{~mm}$ diameter) was cemented.

Particle size was determined by fractional filtration. Five tared sieves containing screens with mesh openings ranging from 34 to $125 \mu \mathrm{m}$ were used for each replicate. Each sieve was placed on the rim of a 1 -litre beaker and held firmly in position by its collar. A 25 -g aliquot of a 


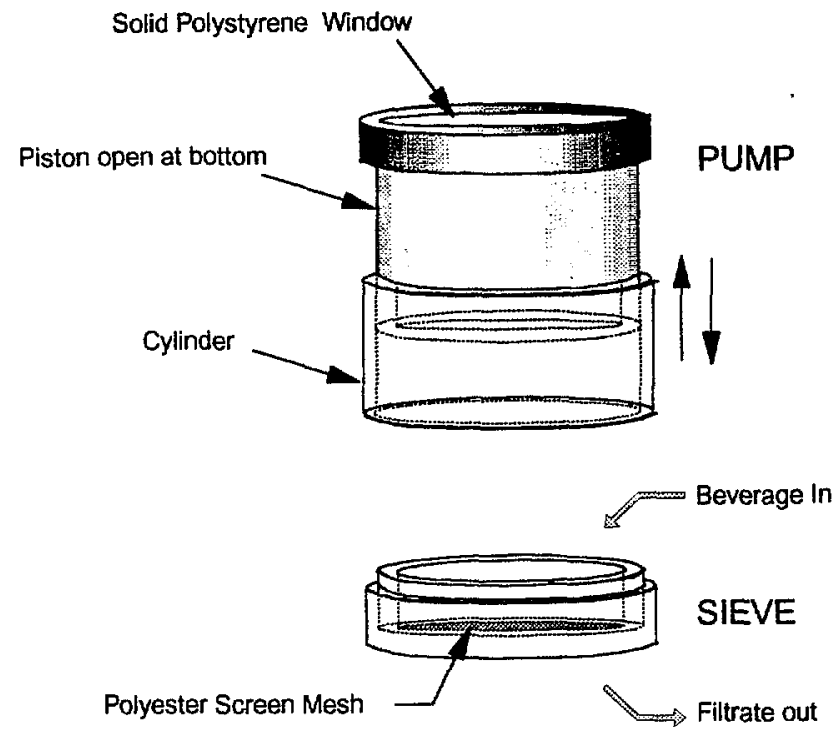

Fig. 1. Schematic of fractional filtration of particles in peanut beverage.

beverage of known solids content was poured into the 126 -mesh $\left(125-\mu \mathrm{m}\right.$ opening) sieve. Tap water $\left(30^{\circ} \mathrm{C}\right)$ was used to wash particles $<125 \mu \mathrm{m}$ diameter through the sieve. The filtrate was poured into the 143-mesh (104- $\mu \mathrm{m}$ opening) sieve through which particles $<104$ $\mu \mathrm{m}$ diameter were passed. Filtration operations through the remaining sieves were continued in sequence (in descending order of mesh diameter openings) until all particles with diameters $<34 \mu \mathrm{m}$ were washed through the 380 mesh sieve. Rate of filtration was increased by resting the frame of the pump on the collar of the sieve and manually applying a gentle pumping action on the piston. Each sieve containing particulate materials was covered with a polystyrene lid $(100 \mathrm{~mm}$ diameter $)$, then dried $(c a 6 \mathrm{~h})$ at $50^{\circ} \mathrm{C}$ (Tenney Benchmaster dryer) on a perforated rack to constant weight to determine the weight of particles retained.

When particles retained on a sieve were $\leq 5 \mathrm{mg}$, their weight was also verified using an inspection procedure in which the quantitative distribution of particles retained on the test sieve and on standard sieves were compared visually. Standard sieves used for comparison were prepared as follows. Samples of slurry used to prepare the peanut beverage were filtered sequentially through sieves with 125 to $34-\mu \mathrm{m}$ openings. The residue on the sieve with $34-\mu \mathrm{m}$ diameter opening was dried to a powdered form. Aliquots of this dried peanut meal equivalent to $1.0,1.5,2.0,2.5,3.0,3.5,4.0,4.5$ and $5.0 \mathrm{mg}$ were weighed separately into tared Petri dishes. The contents of each Petri dish were suspended in tap water and transferred into a clean sieve (34- $\mu$ m opening). The sieve was covered with a polystyrene lid ( $100 \mathrm{~mm}$ diameter), then dried at $50^{\circ} \mathrm{C}$ for $8 \mathrm{~h}$ on a perforated rack. The dried sieve and particulate material served as a standard. To verify the weight of particles
( $\leq 5 \mathrm{mg}$ ) retained from a beverage sample, each test sieve with particulates was compared with each of the nine standard sieves using a magnifying glass. The weight of solids retained on a sieve was expressed as $\mathrm{mg} \mathrm{g}^{-1}$ total solids in the beverage sample. Particle size distribution in commercial beverages was also determined.

\section{Statistical analysis}

ANOVA (General Linear Models procedure) and significant differences between means ( $p \leq 0.05$, Duncan's Multiple Range test) were determined using the SAS computer package (SAS Institute, 1985).

\section{RESULTS AND DISCUSSION}

The solids ( $\left.100 \mathrm{~mL}^{-1}\right)$ content in the peanut beverage samples (Table 1) was within the range observed for commercial low-fat cows' milk (10.7 \pm 0.02$)$, whole cows' milk (11.7 \pm 0.02$)$, chocolate low-fat milk $(15.2 \pm 0.01)$ and chocolate flavored drink (14.2 \pm 0.05$)$. Weights of particles ( $\mathrm{g} 100 \mathrm{~g}^{-1}$ total solids) in peanut beverages with particle diameter $<34 \mu \mathrm{m}$ are listed in Table 1. Values of $99.96 \pm 0.00,99.95 \pm 0.013$, $99.85 \pm 0.004$, and $99.75 \pm 0.016$, respectively, were observed in commercial low-fat cows' milk, whole cows' milk, chocolate low-fat milk and chocolate flavored drink. During beverage preparation, unheated peanut slurries were filtered through screens with $34-\mu \mathrm{m}$ diameter openings. However, not all particles in the controls and heat-processed peanut beverage samples were $\leq 34 \mu \mathrm{m}$ diameter (Table 1). This indicates that heat treatment and homogenization influenced particle size.

Characteristics of the bottle-processed beverage suggest that, with harsher processing conditions $\left(111^{\circ} \mathrm{C}\right)$, larger complexes were formed in formulations containing $\mathrm{HV}$ than in those containing $\mathrm{CM}$ (Table 2). $\mathrm{HV}$, a mono-diglyceride blend, emulsifies by reducing surface tension between oil and water interfaces (Pomeranz, 1991), and probably facilitated the formation of hydrophilic protein-lipid complexes with diameters $>34 \mu \mathrm{m}$. Homogenizing after kettle-pasteurizing appeared to be effective in breaking down most of the complexes ( $>34$ $\mu \mathrm{m}$ ) that were formed during pasteurizing. Higher kettle-pasteurizing temperatures would likely have promoted the formation of protein complexes. However, beverages pasteurized at 77 or $82^{\circ} \mathrm{C}$ contained similar weights of particles with diameters $<34 \mu \mathrm{m}$ (Table 1), indicating that higher homogenizing temperatures probably facilitated dissociation of complexes which were formed during pasteurizing. Soybean beverages with smoother mouthfeel have been obtained using a homogenization temperature of $82^{\circ} \mathrm{C}$ vs $16^{\circ} \mathrm{C}$ (Nelson et al., 1976).

Kettle-pasteurized beverages containing $\mathrm{CM}$ and homogenized at $72^{\circ} \mathrm{C}$ contained significantly less 
Table 1. Total solids $\left(\mathrm{g} 100 \mathrm{~mL}^{-1}\right)$ and solids $\left(\mathrm{g} 100 \mathrm{~g}^{-1}\right.$ total solids, $<34 \mu \mathrm{m}$ diameter) in peanut beverage after 14 days' storage at $1^{\circ} \mathrm{C}^{a}$

\begin{tabular}{|c|c|c|c|c|c|c|c|}
\hline \multirow[b]{2}{*}{ Property } & \multirow[b]{2}{*}{ Emulsifier ${ }^{h}$} & \multirow[t]{2}{*}{ Control } & \multicolumn{2}{|c|}{ Bottle-processed ${ }^{\prime}$} & \multicolumn{3}{|c|}{ Kettle-pasteurized ${ }^{r}$} \\
\hline & & & $72^{\circ} \mathrm{C}$ & $111^{\circ} \mathrm{C}$ & $72^{\circ} \mathrm{C}$ & $77^{\circ} \mathrm{C}$ & $82^{\circ} \mathrm{C}$ \\
\hline Total solids & $\mathrm{CM}$ & $12.6 \pm 0.02 \mathrm{~d}$ & $12.6 \pm 0.07 d$ & $12.6 \pm 0.01 \mathrm{~cd}$ & $12.8 \pm 0.49 \mathrm{~cd}$ & $13.4 \pm 0.17 b$ & $13.3 \pm 0.41 b$ \\
\hline$\left(\mathrm{g} 100 \mathrm{~mL}^{\mathbf{l}}\right)$ & HV & $13.0 \pm 0.03 \mathrm{c}$ & $13.0 \pm 0.03 c$ & $13.0 \pm 0.02 c$ & $13.9 \pm 0.27 \mathrm{a}$ & $13.8 \pm 0.03 a$ & $13.8 \pm 0.28 \mathrm{a}$ \\
\hline Solids (g $100 \mathrm{~g}{ }^{\prime}$ total solids, & $\mathrm{CM}$ & $99.93 \pm 0.005 a$ & $99.91 \pm 0.005 a$ & $99.88 \pm 0.005 a$ & $99.84 \pm 0.024 b$ & $99.90 \pm 0.004 a$ & $99.90 \pm 0.015 a$ \\
\hline$<34 \mu \mathrm{m}$ diameter) & HV & $99.92 \pm 0.000 \mathrm{a}$ & $99.92 \pm 0.005 \mathrm{a}$ & $99.79 \pm 0.050 \mathrm{~b}$ & $99.89 \pm 0.006 \mathrm{a}$ & $99.91 \pm 0.000 \mathrm{a}$ & $99.91 \pm 0.001 \mathrm{a}$ \\
\hline
\end{tabular}

${ }^{a}$ Means ( \pm standard deviations) of triplicate determinations. Means for the same property with the same letter are not significantly different at $p \leq 0.05$.

${ }^{h}$ Stabilizer type: $\mathrm{CM}=$ kappa:iota carrageenan $(3: 1, \mathrm{w}: \mathrm{w}) ; \mathrm{HV}=$ hydrogenated mono-diglyceride.

'Processing time at $111^{\circ} \mathrm{C}$ was 8 min. All other samples were processed for $2 \mathrm{~min}$.

particles with diameters $<34 \mu \mathrm{m}$ than corresponding samples containing HV (Table 1). CM, which contains kappa-carrageenan, stabilizes by forming threadlike networks and protein-polysaccharide complexes (Modliszewski, 1984), and homogenizing at $72^{\circ} \mathrm{C}$ (compared with 77 to $82^{\circ} \mathrm{C}$ ) was less effective in dissociating these complexes. Formulations containing $\mathrm{CM}$ and kettle-pasteurized at $72^{\circ} \mathrm{C}$ contained less particles with diameters $<34 \mu \mathrm{m}$ than similar formulations which were bottle-processed at $72^{\circ} \mathrm{C}$. The presence of 3,6 anhydride groups on $\mathrm{k}$ - and $\mathrm{i}$ - carrageenan molecules favor formation of intermolecular helical conformations in aqueous systems above $50^{\circ} \mathrm{C}$ (Pomeranz, 1991; Samant et al., 1993). During kettle-pasteurizing, beverages were stirred continuously and this may have increased the formation of intermolecular networks by CM.
None of the peanut beverages or commercial beverages contained particles $\geq 125 \mu \mathrm{m}$ in diameter. Table 2 shows the distribution of particles ( $\mathrm{mg} \mathrm{g}^{-1}$ total solids) with diameters which ranged from 34 to $124 \mu \mathrm{m}$. Beverages prepared by Rubico et al., (1987) from unroasted partially-defatted peanuts contained particles $>150 \mu \mathrm{m}$ diameter and were assigned scores of 90 to 100 (on a 1 to 150 scale) for chalkiness. Optimum quality soymilk prepared by Kuntz et al., (1978) contained 0.1 to 0.2 and 1.0 to $1.2 \mathrm{mg} \mathrm{g}^{-1}$ total solids with diameters $>150$ $\mu \mathrm{m}$ and 105 to $149 \mu \mathrm{m}$, respectively. Soymilk formulations were assigned mean scores for chalkiness of 1.6 on a scale in which 1 and 7 represented imperceptible and pronounced chalkiness, respectively. Kuntz et al., (1978) observed that particles (105 to $149 \mu \mathrm{m}$ diameter) in soymilk which were retained by a 150 -mesh screen were primarily responsible for chalkiness and they predicted

Table 2. Distribution of particles ( $\mathrm{mg} \mathrm{g}^{-1}$ total solids) with diameter $>34 \mu \mathrm{m}$ in peanut and commercial beverages ${ }^{a}$

\begin{tabular}{|c|c|c|c|c|c|c|c|}
\hline \multirow[t]{2}{*}{ Beverage } & \multirow[t]{2}{*}{ Treatment } & \multirow{2}{*}{$\begin{array}{l}\text { Processing } \\
\text { Temperature } \\
\left({ }^{\circ} \mathrm{C}\right)\end{array}$} & \multirow{2}{*}{ Emulsifier } & \multicolumn{4}{|c|}{ Diameter of particles $(\mu \mathrm{m})$} \\
\hline & & & & 104 to 124 & 74 to 103 & 53 to 73 & 34 to 52 \\
\hline \multirow[t]{12}{*}{ Peanut } & Control & & $\mathrm{CM}$ & $0.1 \pm 0.0 \mathrm{c}$ & $0.1 \pm 0.1 \mathrm{~d}$ & $0.1 \pm 0.1 d$ & $0.5 \pm 0.0 \mathrm{c}$ \\
\hline & & & HV & $0.1 \pm 0.0 \mathrm{c}$ & $0.1 \pm 0.0 \mathrm{~d}$ & $0.1 \pm 0.0 \mathrm{e}$ & $0.5 \pm 0.0 \mathrm{c}$ \\
\hline & Bottle-processed & 72 & $\mathrm{CM}$ & $0.1 \pm 0.0 \mathrm{c}$ & $0.1 \pm 0.0 \mathrm{~d}$ & $0.2 \pm 0.1 \mathrm{~cd}$ & $0.5 \pm 0.0 \mathrm{c}$ \\
\hline & & & HV & $0.1 \pm 0.0 \mathrm{c}$ & $0.1 \pm 0.0 \mathrm{~d}$ & $0.1 \pm 0.0 \mathrm{e}$ & $0.5 \pm 0.1 \mathrm{c}$ \\
\hline & Bottle-processed & 111 & $\mathrm{CM}$ & $0.3 \pm 0.0 \mathrm{bc}$ & $0.1 \pm 0.0 \mathrm{~d}$ & $0.3 \pm 0.1 \mathrm{c}$ & $0.5 \pm 0.0 \mathrm{c}$ \\
\hline & & & HV & $1.8 \pm 0.7 \mathrm{a}$ & $0.1 \pm 0.0 \mathrm{~d}$ & $0.1 \pm 0.0 \mathrm{e}$ & $0.1 \pm 0.0 \mathrm{~d}$ \\
\hline & Kettle-pasteurized & 72 & $\mathrm{CM}$ & $0.1 \pm 0.0 \mathrm{c}$ & $0.2 \pm 0.0 \mathrm{c}$ & $0.3 \pm 0.1 \mathfrak{c}$ & $1.0 \pm 0.3 \mathrm{a}$ \\
\hline & & & HV & $0.1 \pm 0.0 \mathrm{c}$ & $0.1 \pm 0.0 \mathrm{~d}$ & $0.2 \pm 0.1 \mathrm{de}$ & $0.7 \pm 0.1 b c$ \\
\hline & Kettle-pasteurized & 77 & $\mathrm{CM}$ & $0.1 \pm 0.0 \mathrm{c}$ & $0.1 \pm 0.0 \mathrm{~d}$ & $0.2 \pm 0.0 \mathrm{cde}$ & $0.6 \pm 0.1 \mathrm{bc}$ \\
\hline & & & $\mathrm{HV}$ & $0.1 \pm 0.0 \mathrm{c}$ & $0.1 \pm 0.0 \mathrm{~d}$ & $0.1 \pm 0.0 \mathrm{e}$ & $0.6 \pm 0.0 \mathrm{bc}$ \\
\hline & Kettle-pasteurized & 82 & $\mathrm{CM}$ & $0.1 \pm 0.0 \mathrm{c}$ & $0.1 \pm 0.0 \mathrm{~d}$ & $0.1 \pm 0.0 \mathrm{e}$ & $0.7 \pm 0.1 b c$ \\
\hline & & & HV & $0.1 \pm 0.0 \mathrm{c}$ & $0.1 \pm 0.0 \mathrm{~d}$ & $0.1 \pm 0.0 \mathrm{e}$ & $0.6 \pm 0.1 b c$ \\
\hline \multirow[t]{4}{*}{ Commercial } & $\begin{array}{l}\text { Whole milk } \\
\text { (pasteurized) }\end{array}$ & - & - & $0.2 \pm 0.1 \mathrm{c}$ & $0.1 \pm 0.0 \mathrm{~d}$ & $0.1 \pm 0.0 \mathrm{e}$ & $0.1 \pm 0.1 d$ \\
\hline & $\begin{array}{l}\text { Low-fat milk } \\
\text { (pasteurized) }\end{array}$ & - & - & $0.1 \pm 0.0 c$ & $0.1 \pm 0.0 \mathrm{~d}$ & $0.1 \pm 0.0 \mathrm{e}$ & $0.1 \pm 0.0 \mathrm{~d}$ \\
\hline & Chocolate milk & - & - & $0.3 \pm 0.0 \mathrm{bc}$ & $0.3 \pm 0.1 b$ & $0.4 \pm 0.0 \mathrm{~b}$ & $0.5 \pm 0.0 \mathrm{c}$ \\
\hline & Chocolate drink & - & -- & $0.4 \pm 0.1 b$ & $0.5 \pm 0.2 \mathrm{a}$ & $0.7 \pm 0.0 \mathrm{a}$ & $0.9 \pm 0.0 a b$ \\
\hline
\end{tabular}

${ }^{u}$ Means ( \pm standard deviations) of triplicate determinations. Means for the same particle diameter (column) followed by the same letter are not significantly different at $p \leq 0.05$.

${ }^{h}$ Processing time at $111^{\circ} \mathrm{C}$ was $8 \mathrm{~min}$. All other peanut beverage samples were processed for $2 \mathrm{~min}$.

'Stabilizer type: $\mathrm{CM}=$ kappa:iota carrageenan $(3: \mathrm{l}, \mathrm{w}: \mathrm{w}) ; \mathrm{HV}=$ hydrogenated mono-diglyceride. 
that if all particles were $<105 \mu \mathrm{m}$ diameter, chalkiness would be imperceptible. In our study, the controls, peanut beverage bottle-processed at $72^{\circ} \mathrm{C}$, kettle-pasteurized beverage and commercial low-fat milk contained $0.1 \mathrm{mg} \mathrm{g}^{-1}$ total solids with diameters of 104 to $124 \mu \mathrm{m}$ (Table 2), suggesting that they would impart little or no chalky mouthfeel. Preliminary sensory screening of the peanut beverages by eight trained panelists indicated that the kettle-pasteurized samples had a smoother mouthfeel than the bottle-processed ones.

Peanut beverage containing CM and bottle-processed at $111^{\circ} \mathrm{C}$ had a particle retention on the $104-\mu \mathrm{m}$ screen similar to that of commercial chocolate milk and chocolate drink. The significantly higher proportion of particles with diameters of 104 to $124 \mu \mathrm{m}$ in peanut beverages containing $\mathrm{HV}$ and bottle-processed at $111^{\circ} \mathrm{C}$ suggests that larger lipid-protein complexes were formed by the emulsifying action of $\mathrm{HV}$ than by the stabilising action of $\mathrm{CM}$.

Schmidt et al., (1978) observed a significant reduction in chalkiness when beverages prepared from either unroasted peanuts or soybeans were sieved through 250mesh (60- $\mu$ m diameter openings) screens. In our study, particles with diameters of 53 to $124 \mu \mathrm{m}$ (instead of 60 $\mu \mathrm{m})$ in peanut beverages and commercial beverages were determined (Table 2). Controls, beverages kettlepasteurized at 77 or $82^{\circ} \mathrm{C}$, and formulations containing HV which were either bottle-processed or kettle-pasteurized at $72^{\circ} \mathrm{C}$, were characterized by a distribution of particles with diameters of 53 to $124 \mu \mathrm{m}$ that were similar to those of commercial low-fat and whole cows' milks (Table 2). On the other hand, more particles were retained from commercial chocolate low-fat milk and chocolate drink on 104-, 74- and 53- $\mu \mathrm{m}$ screens than from peanut beverages, except those which were bottleprocessed at $111^{\circ} \mathrm{C}$. These observations and those of Schmidt et al., (1978) indicate that peanut beverages bottle-processed at $72^{\circ} \mathrm{C}$ or kettle-pasteurized at 72,77 or $82^{\circ} \mathrm{C}$ would be less chalky than commercial chocolate low-fat milk and chocolate drink, and may be similar in smoothness to commercial low-fat and whole cows' milks.

Controls, peanut beverages kettle-pasteurized at 77 or $82^{\circ} \mathrm{C}$, and formulations containing $\mathrm{HV}$ which were either bottle-processed or kettle-pasteurized at $72^{\circ} \mathrm{C}$ had particle retention similar to that of commercial low-fat and whole (cows') milks on all screens except 34- $\mu \mathrm{m}$ screens on which significantly fewer particles were retained from the commercial milks (Table 2). Higher viscosity of the dispersion medium in beverages decreases the chalkiness perceived from particles of similar sizes (Kokini, 1987). Viscosities of commercial cows' milks were $2.0 \pm 0.0 \mathrm{cps}$ compared with $2.0 \pm 0.0$ to $2.4 \pm 0.0$ and $6.4 \pm 0.91$ to $7.4 \pm 0.35 \mathrm{cps}$ for controls and kettle-pasteurized $\left(77\right.$ or $82^{\circ} \mathrm{C}$ ) peanut beverages, respectively (Hinds et al., 1997a). Formulations con- taining HV that were bottle-processed or kettle- pasteurized at $72^{\circ} \mathrm{C}$ had viscosities of $8.4 \pm 0.44$ and $2.1 \pm 0.0 \mathrm{cps}$, respectively (Hinds et al., 1997a). These observations indicate that peanut beverages which were kettle-pasteurized at 77 or $82^{\circ} \mathrm{C}$, as well as those containing $\mathrm{HV}$ and kettle-pasteurized at $72^{\circ} \mathrm{C}$ would impart a less chalky mouthfeel than commercial chocolate drink which contained the most particles with diameters $>34 \mu \mathrm{m}$ (Table 2) and had a viscosity of $4.9 \pm 0.06 \mathrm{cps}$ (Hinds et al., 1997a).

The relative viscosities and particle size distribution also suggest that peanut beverages which were kettlepasteurized at 77 or $82^{\circ} \mathrm{C}$, as well as those containing $\mathrm{HV}$ and kettle-pasteurized at $72^{\circ} \mathrm{C}$ may impart a mouthfeel similar to that of commercial cows' milk. However, the influence on overall mouthfeel or relative densities of particles with diameters 34 to $52 \mu \mathrm{m}$ needs to be confirmed by a trained sensory panel. Pasteurizing at 77 to $82^{\circ} \mathrm{C}$ compared with $72^{\circ} \mathrm{C}$ would promote longer shelf-life. Therefore, beverages which are kettlepasteurized at 77 to $82^{\circ} \mathrm{C}$, then homogenized, would be expected to have optimum mouthfeel and shelf-life and would impart a less chalky mouthfeel than reported for soymilk (Kuntz et al., 1978) and peanut beverage (Rubico et al., 1987). Information on particle size distribution will be important for further research to produce a peanut beverage with optimal combinations of small particle size, smooth mouthfeel, viscosity similar to full-fat milk, physical stability, roasted peanut flavor, and reasonable shelf-life. Samples from the optimization study will be evaluated thoroughly by trained sensory panelists.

\section{ACKNOWLEDGEMENTS}

This research was supported in part by the Peanut Collaborative Research Support Program of U.S. Agency for International Development, USAID grant No. DAN-4048-G-0041-00. The authors are grateful to Glen Farrell for design and fabrication of the filters, sieves and pump.

\section{REFERENCES}

Banon, S. and Hardy, J. (1992) A colloidal approach to milk acidification by glucono-delta-lactone. Journal Dairy Sci. $75,935-941$.

Chrompreeda, P., Haruthaithanasan, V., Oupadissakoon, C. and Suknak, K. (1989) Development of a chocolate flavored peanut beverage. Journal Food Sci. 54, 1359-1360.

Galvez, F. C. F., Resurreccion, A. V. A. and Koehler, P. E. (1990) Optimization of processing of peanut beverage. Journal Sensory Stud. 5, 1-17.

Hinds, M. J., Beuchat, L. R. and Chinnan, M. S. (1997a) Physical properties of thermal-processed beverage prepared from roasted partially defatted peanuts. Int. Joumal Food Sci. Technol. (Submitted). 
Hinds, M. J., Beuchat, L. R. and Chinnan, M. S. (1997b) Effects of homogenization pressure and stabilizers on some physical characteristics of a beverage prepared from partially defatted peanuts. Plant Foods Human Nutr. (Submitted).

Holcomb, D. N., Pechak, D. G., Chakrabarte, S. and Opsahl, A. (1992) Visualizing textural changes in dairy products by. image analysis. Food Technol. 46(1), 122-125,127.

Kokini, J. L. (1987) The physical basis of liquid food texture and texture-taste interactions. Journal Food Eng 6, 51-81.

Kuntz, D. A., Nelson, A. I., Steinberg, M. P. and Wei, L. S. (1978) Control of chalkiness in soymilk. Journal Food Sci. 43, 1279-1283.

Lee, C. and Beuchat, L. R. (1992) Chemical, physical and sensory characteristics of peanut milk as affected by processing conditions. Journal Food Sci. 57, 401-405.

Modliskzewski, J. J. (1984) In Gum and Starch Technology, 18th Annual Symposium, ed. D. L. Downing. pp. 25-31. Cornell University, Ithaca, NY.

Nelson, A. I., Steinberg, M. P. and Wei, L. S. (1976) Illinois process for preparation of soymilk. Journal Food Sci. 41, 57-61.

Paquin, P., Robin, O. and Richard, J. P. (1991) Evaluation of the particle size of fat globules from model emulsion or homogenizing milk by photon correlation spectroscopy. Journal Dairy Sci. 73, 90.

Pomeranz, Y. (1991) In Functional Properties of Food Components, 2nd edn. pp. 79-115 and 248-380. Academic Press, Inc., San Diego.

Rubico, S. M., Resurreccion, A. V. A., Frank, J. F. and Beuchat, L. R. (1987) Suspension stability, texture and color of high temperature treated peanut beverage. Journal Food Sci. 52, 1676-1679.

Samant, S. K., Singhal, R. S., Kulkarni, P. R. and Rege, D. V. (1993) Protein-polysaccharide interactions: a new approach in food formulations. Int. Journal Food Sci. Technol. 28, $547-562$.

SAS Institute, Inc. (1985) Statistical Analysis System User's Guide: Statistics, Version 5 edn. Cary, NC, USA.

Schmidt, R. H., Surak, J. G., Hausknecht, D. R. and Haile, D. G. (1978) Particle size distribution in citrus flavored soybean and peanut milk beverages. Proc. Florida State Hort. Soc. 91, 153-156.

Szczesniak, A. S. (1979) In Food Texture and Rheology, ed. P. Sherman, pp. 1-20 Academic Press, New York.

(Received 8 November 1996; accepted 1 February 1997) 